\title{
ESTIMATION OF SULFENTRAZONE SORPTION IN ISOLATED APPLICATION AND MIXED WITH GLYPHOSATE
}

\author{
ESTIMATIVA DA SORÇÃO DO SULFENTRAZONE EM APLICAÇÃO ISOLADA E \\ EM MISTURA COM GLYPHOSATE
}

\author{
Ana Claudia LANGARO'; ${ }^{\mathbf{3}}$ João Pedro Ambrosio BARROS ${ }^{1}$; \\ Gustavo Antônio Mendes PEREIRA ${ }^{\mathbf{1}}$; Antonio Alberto da SILVA ${ }^{\mathbf{1}}$ \\ 1. Universidade Federal de Viçosa, Campus Viçosa, Viçosa, MG, Brasil. langaro.ac@gmail.com
}

\begin{abstract}
The use of herbicides belonging to a single mechanism of action for several consecutive years in the same area may lead to the selection of weed biotypes resistant to herbicides. Weeds resistant to glyphosate have been problem worldwide. As an alternative control, farmers have used glyphosate mixed with sulfentrazone. When two herbicides are mixed, the parameters that govern the behaviour of herbicides in the soil can be altered. In this study, the sorption of sulfentrazone was estimated when applied in isolation with glyphosate formulations. For this, increasing doses of sulfentrazone were applied using Red-Yellow Latosol substrate and washed sand. Each dose of sulfentrazone was applied in a mixture with $1080 \mathrm{~g}$ a. e. ha ${ }^{-1}$ Roundup Ready ${ }^{\circledR}$, Roundup Ultra ${ }^{\circledR}$ and Zapp Qi ${ }^{\circledR}$. To evaluate the presence of sulfentrazone in the soil solution, Sorghum bicolor was used as an indicator species. Symptoms of intoxication were evaluated at 7, 14 and 21 days after sowing. At 21 days after sowing, the plants were collected and dried in an oven at $70 \pm 10{ }^{\circ} \mathrm{C}$ to determine the dry matter. Based on the intoxication of the indicator plants, it was verified that, regardless of the formulation, the presence of glyphosate in the mixture increased the sorption of sulfentrazone in the Red-Yellow Latosol. However, based on dry matter accumulation, sulfentrazone sorption increased because of the mixture with Roundup Ultra ${ }^{\circledR}$, but decreased due to the presence of Roundup Ready ${ }^{\circledR}$ and Zapp Qi ${ }^{\circledR}$. Therefore, the application of sulfentrazone in mixture with glyphosate alters the sorptive forces of sulfentrazone in a RedYellow Latosol.
\end{abstract}

KEYWORDS: Herbicide. Behaviour. Soil. Bioassay. Sorghum bicolor.

\section{INTRODUCTION}

The sorption and mobility of sulfentrazone in the soil depends mainly on the physical characteristics of the soil and $\mathrm{pH}$. In soil with low $\mathrm{pH}$, high organic matter and high clay content, sulfentrazone sorption in soil solid phase increases and mobility decreases (GREY et al., 1997; OHMES; MUELLER, 2007). Sulfentrazone is relatively persistent in soil, with a pKa of 6.56, solubility increasing with $\mathrm{pH}\left(\mathrm{pH} 6.0=110 \mathrm{mg} \mathrm{L}^{-1}\right.$; $\mathrm{pH} 7.5=1600 \mathrm{mg} \mathrm{L}^{-1}$ ) and a half-life reported for field and laboratory experiments in the range of 24302 days (HATZIOS, 1998; FMC Corporation 1999; OHMES et al., 2000; MARTINEZ et al., 2008). Soil dissipation occurs mainly through microbial degradation. Due to slow degradation, carryover problems can occur, which is a concern for rotational and succession crops (OHMES et al., 2000; MAIN et al., 2004).

All these processes mentioned above are strongly influenced by the sorption process, which corresponds to the retention capacity of the herbicide molecule to the soil surface. Typically, the greater the sorption of the herbicide by the colloids in the soil, the lower its degradation and mobility (MARCHESE, 2007). Studies involving the sorption of herbicides in Brazilian soils are fundamental for evaluating the weed control efficiency of sites, since high sorption indices can compromise the efficiency of herbicides used in preemergence. However, they may have high risks of groundwater contamination (SILVA et al., 2013).

Quantification of the sorption of an herbicide in the soil is usually accomplished by chromatography. However, several studies have shown the possibility of estimating sorption using biological tests. The use of the biological method has some advantages in relation to the others, because it has a low cost and may even be more sensitive to low concentrations of herbicides in the soil (SANDÍN-ESPAÑA et al., 2011). This method can be effective for herbicides applied at both high and extremely low doses (PESSALA et al., 2004).

In biological assays, active biomonitoring is carried out, because test organisms that are highly sensitive to the herbicide are used. Normally, biomonitoring is carried out in a protected 
Estimation of sulfentrazone...

environment that allows the optimal growth of the indicator species (RAYA-RODRIGUEZ, 2000). Their use is based on the exposure of test organisms to various concentrations of one or more substances or environmental factors for a period sufficient to induce a biological response (GHERARDIGOLDSTEIN et al., 1990).

By using the dose-response curve, it is possible to determine the $\mathrm{C}_{50}$, i.e. the dose of sulfentrazone required to cause a 50\% intoxication of plants. This index can be used to calculate the sorption ratio through the soil/sand ratio. Linear regression, described by Streibig et al. (1993) and adapted by Seefeldt et al. (1995), has been the most commonly used method to evaluate and interpret bioassays.

Due to difficulties in glyphosate-resistant weed control, new alternatives have emerged, such as the use of post-emergent and residual herbicide mixtures in burndown, ensuring a broader control spectrum. One of the widely used mixtures has been glyphosate and sulfentrazone in soybean (MINOZZI et al., 2014). Although sulfentrazone in the soil is available in the literature (SZMIGIELSKI et al., 2009; SHANER, 2012; MASHAYAMOMBE et al.,
LANGARO, A. C. et al.

2013; NALINI et al., 2016). Nothing is known about the dynamics of sulfentrazone when applied in admixture with glyphosate. This fact justifies this study that aimed to estimate the sorption of sulfentrazone in isolated application and in mixture with different formulations of glyphosate.

\section{MATERIAL AND METHODS}

The experiment was carried out in a greenhouse in 2016. The samples of Red-Yellow Latosol from the region of Viçosa-MG were collected in the superficial layer $(0-20 \mathrm{~cm})$ dried in the shade, sieved through $2 \mathrm{~mm}$ mesh and subsequently characterised chemically and physically (Table 1).

As an inert substrate, washed sand was used to prepare the standard sorption curve. The sand was sieved in a $2 \mathrm{~mm}$ mesh and then treated for 36 hours with $6 \%(\mathrm{v} / \mathrm{v})$ hydrochloric acid in water. A $10 \mathrm{~cm}$ solution depth was maintained above the substrate level. The sand was then washed with running water until the excess acid was removed, reaching $\mathrm{pH}$ about 7.0 in deionised water.

Table 1. Results of the physical and chemical analysis of the samples of the Red-Yellow Latosol used in the experiment. ${ }^{\mathrm{a}}$

\begin{tabular}{|c|c|c|c|c|c|c|c|c|c|}
\hline \multirow{2}{*}{\multicolumn{3}{|c|}{ Sand $(\%)$}} & \multicolumn{3}{|c|}{ Loam (\%) } & \multicolumn{3}{|c|}{ Clay (\%) } & \multirow[b]{3}{*}{ OM } \\
\hline & & & & 7 & & & 17 & & \\
\hline $\mathrm{pH}$ & $\mathbf{P}$ & $\mathbf{K}^{+}$ & $\mathrm{Ca}^{2+}$ & $\mathrm{Mg}^{2+}$ & $\mathbf{A l}^{3+}$ & $\mathbf{H}+\mathbf{A l}$ & SB & CEC(t) & \\
\hline $\mathrm{H}_{2} \mathrm{O}$ & -..-- & - & - & -cmolc dm ${ }^{-3}$ & & & & & dag $\mathrm{kg}^{-1}$ \\
\hline 4,7 & 2,33 & 41 & 2,2 & 0,7 & 0,2 & 5,61 & 3 & 3,2 & 2,52 \\
\hline
\end{tabular}

a / Analyzes carried out in the Laboratory of Analysis of Soil Viçosa; $\mathrm{pH}$ - Hydrogen potential; P - Phosphor; $\mathrm{K}^{+}$- Potassium; Ca ${ }^{2+}$ Calcium; $\mathrm{Mg}^{2+}$ - Magnesium; $\mathrm{Al}^{3+}$ - Aluminum; $\mathrm{H}+\mathrm{Al}$ - Potential acidity; SB - Sum of bases; CEC - Cation exchange capacity; OM Organic matter.

In order to determine the dose of glyphosate to be used mixed with sulfentrazone, a preliminary assay was performed using crescent rates of glyphosate formulations on the Red-Yellow Latosol and washed sand. In addition, this study aimed to ensure that the visual effect of intoxication of plants was only due to the application of sulfentrazone, not glyphosate. For the preliminary test, samples of a Red-Yellow Latosol were sifted and placed in plastic containers with volumetric capacity of $0.3 \mathrm{~L}$, and glyphosate (Roundup Ready ${ }^{\circledR}$, Roundup Ultra ${ }^{\circledR}$ and Zapp $\mathrm{Qi}^{\circledR}$ ) was applied. The rates of glyphosate used in this preliminary test ranged from $0-2160 \mathrm{~g}$ a. e. ha $^{-1}$ for Red-Yellow Latosol and from 0-540 g a. e. $\mathrm{ha}^{-1}$ for washed sand. To determine the effect of glyphosate, sorghum (Sorghum bicolor) was used as a bioindicator. Based on this study, $1080 \mathrm{~g}$ a. e. $\mathrm{ha}^{-1}$ was adopted for glyphosate.
For the sulfentrazone sorption test, samples of Red-Yellow Latosol were sieved and placed in plastic pots with volumetric capacities of $0.3 \mathrm{~L}$. Five seeds of the bioindicator species (Sorghum bicolor) were then sowed per pot and sulfentrazone $\left(\right.$ Boral $^{\circledR}$ ) at different rates according to the substrate (Table 2) was applied. For application of the herbicide on the pot surface, a $\mathrm{CO}_{2}$ pressurised precision sprayer equipped with TTI 11002 spray tips, calibrated to apply a volume of $150 \mathrm{~L} \mathrm{ha}^{-1}$ was used. In order to avoid drift, the applications were carried out at 25 ${ }^{\circ} \mathrm{C}$ room temperature, $3 \mathrm{~km} \mathrm{~h}^{-1}$ wind and $70 \%$ relative humidity.

The experimental design was completely randomised, with four replications. The treatments corresponded to twelve rates of sulfentrazone in isolated application or mixed with $1080 \mathrm{~g}$ a. e. $\mathrm{ha}^{-1}$ of each glyphosate formulation (Roundup Ready ${ }^{\circledR}$, 
Roundup Ultra ${ }^{\circledR}$ and Zapp $\mathrm{Qi}^{\circledR}$ ) (Table 2). Only sulfentrazone was applied to the washed sand.

Table 2. Rates of sulfentrazone ( $\mathrm{g}$ ae ha $\mathrm{a}^{-1}$ ) applied to Red-Yellow Latosol and sand.

\begin{tabular}{lll}
\hline ID & Red-Yellow Latosol & Washed Sand \\
\hline R0 & 0 & 0 \\
R1 & 10 & 2,5 \\
R2 & 25 & 5 \\
R3 & 50 & 7,5 \\
R4 & 100 & 12,5 \\
R5 & 150 & 25 \\
R6 & 200 & 50 \\
R7 & 250 & 75 \\
R8 & 300 & 100 \\
R9 & 400 & 150 \\
R10 & 500 & 200 \\
R11 & 600 & 250 \\
R12 & 700 & 300 \\
\hline
\end{tabular}

All doses of sulfentrazone applied to Red-Yellow Latosol were mixed with $1080 \mathrm{~g}^{\mathrm{ae}} \mathrm{ha}^{-1}$ of Roundup Ultra ${ }^{\circledR}$, Roundup Ready ${ }^{\circledR}$ and Zapp $\mathrm{Qi}^{\circledR}$ formulations, except for rate zero.

The sorghum was cultivated in soil samples submitted to application of each dose of sulfentrazone alone and mixed with glyphosate for 21 days. During this period, the soil moisture in the pots was maintained close to the field capacity, replacing evapotranspiration water daily. Intoxication evaluations were performed by three evaluators at 7,14 and 21 days after sowing (DAS). At that time, a visual evaluation of the intoxication symptoms of these plants was made, assigning scores from 0 (absence of intoxication symptoms) to 100 (plant death) (Frans et al., 1986). At 21 DAS, shoots were collected to determine the dry matter. For this, the collected plants were dried in oven (70 $\pm 2{ }^{\circ} \mathrm{C}$ ) until reaching a constant mass and then, using a balance with a precision of $0.001 \mathrm{~g}$, the shoot dry matter was determined.

In order to evaluate the intoxication and dry matter of sulfentrazone bioindicators as a function of the increasing rates, a dispersion graph was used (intoxication on the $\mathrm{Y}$-axis and, sulfentrazone rates on the $\mathrm{X}$-axis). The data were adjusted to the nonlinear regression model proposed by Streibig et al. (1993) and adapted by Seefeldt et al. (1995):

$y=\mathrm{C}+\frac{D-C}{1+\left(\frac{x}{C 50}\right)^{b}}$

(equation 1)

Where $y$ is intoxication, $x$ is the herbicide rate $\left(\mathrm{g}\right.$ a. i. ha ${ }^{-1}$ ) and $\mathrm{C}, D, C_{50}$ and $b$ are estimated parameters of the equation. The variable $D$ is the upper limit of the curve, $C$ is the lower limit of the curve, $C_{50}$ is the rate that provides $50 \%$ response of the variable and $b$ is the slope of the curve around $C_{50}$.
From $\mathrm{C}_{50}$ data, the sorption ratio for sulfentrazone was calculated in isolated application and mixed with glyphosate, by the following equation:

$$
S R=\frac{c 50 \operatorname{sonl}-c 50 \text { sand }}{c 50 \text { sand }} \quad(\text { equation } 2)
$$

Where $S R$ is the sorption ratio and $C_{50}$ is the estimated curve parameter representing the dose giving $50 \%$ response of the variable.

In order to verify if the difference between the $\mathrm{C}_{50}$ of sulfentrazone applied alone and mixed with glyphosate is significant, a comparison was made between the confidence intervals of each treatment. The software R Version 1.0.1433.4.3 - (C) 2009-2018 was used for the analyses, with the aid of the "drm", "Rcpp" and "drc" packages. The graphical analyses were done using the program SigmaPlot 12.0 (Exact Graphs and Data Analysis) for Windows.

\section{RESULTS AND DISCUSSION}

Based on the preliminary test results, glyphosate, when applied during pre-emergence, does not cause intoxication in sorghum plants, even when applied at the highest dose (data not shown). Thus, the dose of $1080 \mathrm{~g}$ a. e. $\mathrm{ha}^{-1}$, for all formulations of glyphosate, was mixed with sulfentrazone. The sorption of glyphosate is related to the Van der Waals forces, hydrogen bonds with the humic substances of the soil, ion exchange and the covalent bonding with the metallic oxides of the soil, mainly iron oxides (similar to the specific 
adsorption of inorganic phosphates). This is the most important mechanism for oxidative soils (PRATA et al., 2005) that keeps the glyphosate adsorbed to the soil and not absorbed by the indicator plant (PRATA et al., 2000; COUTINHO; MAZZO, 2005; TONI et al., 2006).

The bioassay method was efficient in determining sulfentrazone sorption as a function of

\section{Red-Yellow Latosol}

\section{DAS}

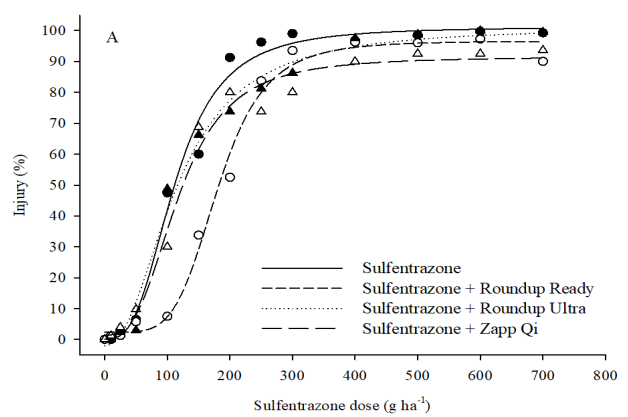

14 DAS

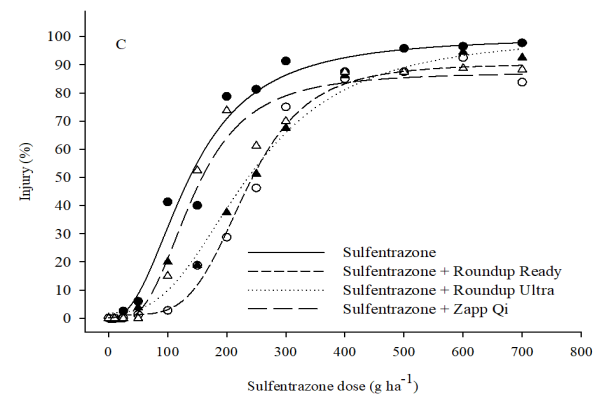

\section{DAS}

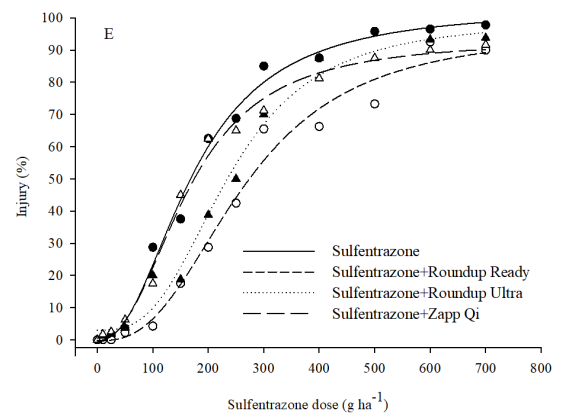

the applied treatment. The graphs of sorghum (cultivated in Red-Yellow Latosol and washed sand) intoxication as a function of the increasing rates of sulfentrazone are presented in Figure 1. The equations referring to the non-linear regression model proposed by Streibig et al. (1993) and adapted by Seefeldt et al. (1995) are shown in Table 3.

\section{Washed Sand}
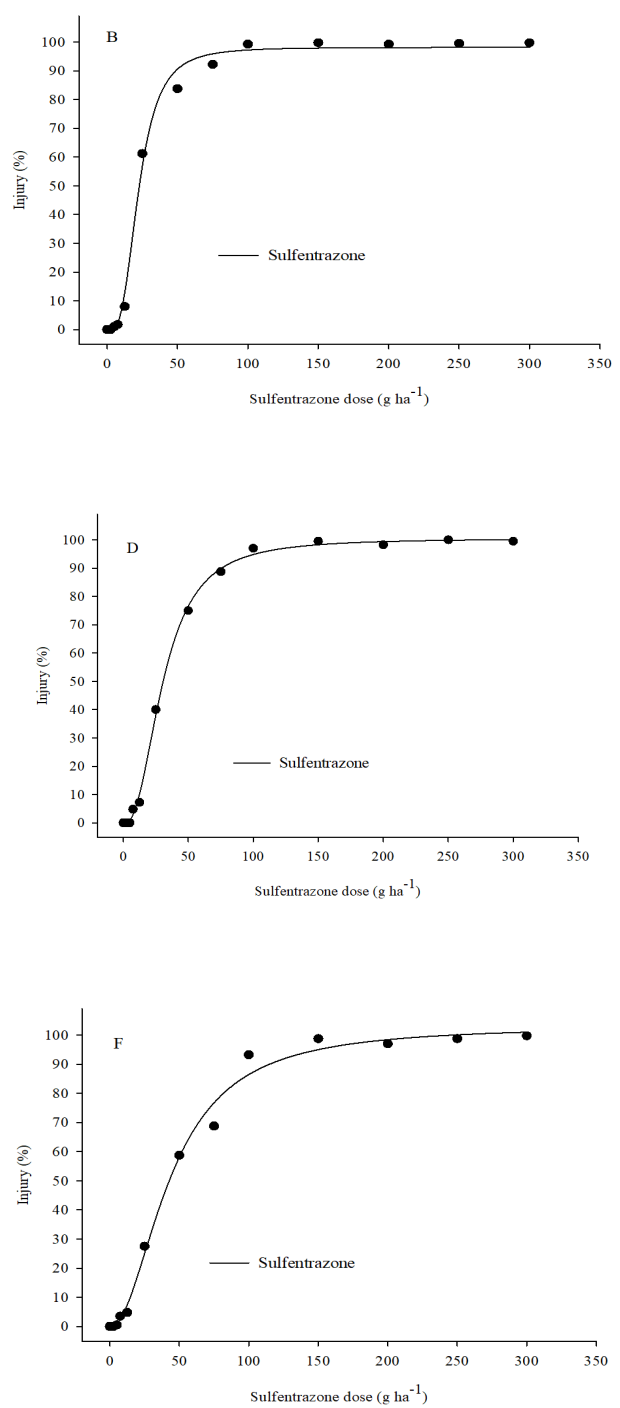

Figure 1. Injury of sorghum plants cultivated in Red-Yellow Latosol (A, C, E) and washed sand (B, D, F) submitted to increasing rates of sulfentrazone alone and mixed with glyphosate formulations at 7 (A, B), 14 (C, D) and 21 (E, F) days after sowing (DAS) of bioindicator species.

The rate of glyphosate used was $1080 \mathrm{~g}$ ae ha- ${ }^{-1}$ for all treatments, except sand. 
Table 3. Equation for sorption of sulfentrazone isolated and mixed with glyphosate formulations based on intoxication at 7, 14 and 21 days after sowing (DAS) of the bioindicator species.

\begin{tabular}{|c|c|c|}
\hline Treatments & Equations & $\mathbf{R}^{2}$ \\
\hline & 7 DAS & \\
\hline \multirow[b]{2}{*}{ Washed Sand } & \multirow{2}{*}{$y=-1,433+\frac{98,1953+1,0443}{1+\left(\frac{x}{22,4775}\right)^{-3,1122}}$} & \multirow[b]{2}{*}{0,9954} \\
\hline & & \\
\hline Sulfentrazone & $\begin{array}{c}y=0,1772+\frac{x}{1+\left(\frac{x}{112,4377}\right)^{-2,9568}} \\
96,6135-2,3565\end{array}$ & 0,9905 \\
\hline Sulfentrazone+Roundup Ready ${ }^{\circledR}$ & $y=2,3565+\frac{x}{1+\left(\frac{x}{181,5155}\right)^{-4,8184}}$ & 0,9920 \\
\hline Sulfentrazone+Roundup Ultra ${ }^{\circledR}$ & $\begin{aligned} & y=-1,9752+ \frac{101,0695+1,9752}{1+\left(\frac{x}{115,3912}\right)^{-2,1989}} \\
& 91,5532-1,4739\end{aligned}$ & 0,9905 \\
\hline Sulfentrazone+Zapp Qi ${ }^{\circledR}$ & $y=1,4739+\frac{x}{1+\left(\frac{x}{118,4768}\right)^{-2,9494}}$ & 0,9871 \\
\hline & 14 DAS & \\
\hline Washed Sand & $y=-0,4867+\frac{100,5302+0,4867}{1+\left(\frac{x}{30,6591}\right)^{-2,3856}}$ & 0,9989 \\
\hline Sulfentrazone & $\begin{array}{c}y=0,0712+\frac{x}{1+\left(\frac{x}{137,0630}\right)^{-2,3580}} \\
90,3998-1,1543\end{array}$ & 0,9788 \\
\hline Sulfentrazone+Roundup Ready ${ }^{\circledR}$ & $\begin{array}{c}y=1,1543+\frac{x}{1+\left(\frac{x}{233,4120}\right)^{-4,5246}} \\
100,4211-1,8672\end{array}$ & 0,9898 \\
\hline Sulfentrazone+Roundup Ultra ${ }^{\circledR}$ & $\begin{array}{r}y=1,8672+\frac{x}{1+\left(\frac{x}{240,0190}\right)^{-2,7788}} \\
91,5532-1,4147\end{array}$ & 0,9898 \\
\hline Sulfentrazone+Zapp Qi ${ }^{\circledR}$ & $y=-1,4147+\frac{x}{1+\left(\frac{x}{142,3854}\right)^{-3,0459}}$ & 0,9754 \\
\hline & 21 DAS & \\
\hline Washed Sand & $\begin{array}{r}y=-0,4026+\frac{103,1837+0,4026}{1+\left(\frac{x}{43,8862}\right)^{2,0020}} \\
102,7828+0,2108\end{array}$ & 0,9939 \\
\hline Sulfentrazone & $\begin{array}{c}y=-0,2108+\frac{x}{1+\left(\frac{x}{171,7148}\right)^{2,2558}} \\
96,0664+0,2817\end{array}$ & 0,9940 \\
\hline Sulfentrazone+Roundup Ready ${ }^{\circledR}$ & $\begin{aligned} & y=-0,2817+ \frac{x}{1+\left(\frac{x}{264,9434}\right)^{2,6432}} \\
& 99,2447-3,0237\end{aligned}$ & 0,9847 \\
\hline Sulfentrazone+Roundup Ultra ${ }^{\circledR}$ & $\begin{array}{r}y=3,0237+\frac{x}{1+\left(\frac{x}{237,9700}\right)^{2,9599}} \\
92,9007-0,6530\end{array}$ & 0,9890 \\
\hline Sulfentrazone+Zapp Qi ${ }^{\circledR}$ & $y=0,6530+\frac{x}{1+\left(\frac{x}{164,4350}\right)^{2,3677}}$ & 0,9431 \\
\hline
\end{tabular}

In general, an increase in the intoxication symptoms of sorghum plants due to the increase of herbicide rates was observed, regardless of glyphosate formulation. The data were adjusted appropriately to the proposed model for all the evaluation periods (7, 14 and 21 DAS) and treatments. The coefficient of determination ranged from 0.9754 to 0.9989 , except for sulfentrazone + Zapp Qi ${ }^{\circledR}$ at 21 DAS.

The $\mathrm{C}_{50}$ values determined for sulfentrazone in washed sand were $22.48,30.66$ and $43.89 \mathrm{~g}$ i. a. $\mathrm{ha}^{-1}$ at 7, 14 and $21 \mathrm{DAS}$, respectively. The low 
Estimation of sulfentrazone...

values were due to reduced number of binding sites present in the washed sand (inert material) when compared to the soil. In that case, the herbicide was predominantly available in the soil solution and could be readily absorbed by the bioindicator, thus altering its growth and development. The determination of the $\mathrm{C}_{50}$ in washed sand is extremely important for the calculation of the sorption ratio.

As regards the $\mathrm{C}_{50}$ obtained as function of the intoxication in the soil, in general, higher rates of sulfentrazone were necessary to cause a $50 \%$ response when sulfentrazone was applied in a mixture with glyphosate (Table 3). This result indicates that, when mixed with glyphosate, sulfentrazone sorption in the Red-Yellow Latosol was higher when compared to the isolated application of sulfentrazone.

The sorption process is the primary factor that influences the effectiveness of herbicides applied to soil. From the toxicological point of view, herbicide retention reduces the available concentration in the soil solution for microbial degradation, uptake by plants, and leaching into the soil profile (SOUZA et al., 2016). The physical and chemical characteristics of the herbicide molecule and the soil define the capacity and intensity of the sorption and desorption of an herbicide to the soil, and consequently the ability of these compounds to contaminate the environment (ČADKOVÁ et al., 2013; SOUZA et al., 2016). When applied in a mixture, interactions between these molecules can occur, altering the sorption processes and consequently the behaviour of one or both molecules.

Similar behaviour was observed by Souza (2017) studying the influence of glyphosate on the behaviour of atrazine in a Red-Yellow Latosol. Using biological assay and cucumber as an indicator plant, the author observed a higher sorption of atrazine when applied in a mixture with Roundup Ultra $^{\circledR}$ and a reduction in sorption when applied mixed with Roundup Ready ${ }^{\circledR}$ and Zapp Qi ${ }^{\circledR}$.

The presence of surfactants and adjuvants in the formulated product Roundup Ultra ${ }^{\circledR}$ may cause changes in the physicochemical characteristics of the water present in the soil solution, such as electrical conductivity, surface tension and $\mathrm{pH}$ (DA CUNHA; ALVES, 2009; BAIO et al. 2015). The reduction of $\mathrm{pH}$ may favour the sorption of sulfentrazone in the soil, since it has a weak acid behaviour. In this case, when the $\mathrm{pH}$ of the soil is lower than the $\mathrm{pKa}$ of the herbicide, the molecular
LANGARO, A. C. et al.

form prevails, favouring the sorption of the herbicide in the soil. In the present study, the soil $\mathrm{pH}$ was 4.7 and the $\mathrm{pKa}$ of sulfentrazone is 6.56 .

The dry matter of sorghum plants cultivated in the Red-Yellow Latosol and washed sand, as a function of the increasing rates of sulfentrazone applied in isolation and mixed with glyphosate can be observed in Figure 2. The reduction in the dry matter of the bioindicator plants with an increasing dose of herbicide, regardless of the treatment, was observed. Based on the dry matter of the bioindicator plants, a greater amount of sulfentrazone was needed to reduce the dry matter by $50 \%$ when the application was carried out in a mixture with Roundup Ultra ${ }^{\circledR}$. This rate increase is approximately $55 \%$ higher compared to the application of sulfentrazone alone, indicating a higher sorption of sulfentrazone as a function of the mixture. An opposite behaviour is observed when sulfentrazone was applied in a mixture with Roundup Ready ${ }^{\circledR}$ and Zapp Q $i^{\circledR}$. In this case, the rate required to reduce biomass by $50 \%$ was 38 and $53 \%$ lower when sulfentrazone was applied in a mixture with Roundup Ready ${ }^{\circledR}$ and Zapp $\mathrm{Qi}^{\circledR}$, respectively.

The sorption ratio of sulfentrazone applied in isolation and mixed with different formulations of glyphosate, based on the observed intoxication and dry matter of the indicator plant, is shown in Table 4. Based on the sorption ratio calculated from the intoxication, the mixture with glyphosate increased the sorption of sulfentrazone in the Red-Yellow Latosol, regardless of the formulation used.

One of the reasons this may occur is related to the interaction between the herbicidal molecules. It is known that glyphosate, when in contact with the soil, is strongly sorbed to the colloidal fraction (BORGGAARD; GIMSING, 2008). The authors believe that glyphosate attached to soil colloids may also serve as binding sites for other molecules, resulting in an increased sorption of sulfentrazone.

To verify whether the difference between the $\mathrm{C}_{50}$ of sulfentrazone applied alone and in mixtures with glyphosate was significant, a comparison was made using the confidence intervals of each treatment. The software $\mathrm{R}$ Version 1.0.1433.4.3-@ 2009-2018 was used for the analyses, with the aid of the "drm", "Rcpp" and "drc" packages. This test was used to obtain the P values, which are shown in Table 5. When the $P$ value is lower than or equal to 0.05 the difference between the coefficients $\left(\mathrm{C}_{50}\right)$ is significant. 
Red-Yellow Latosol

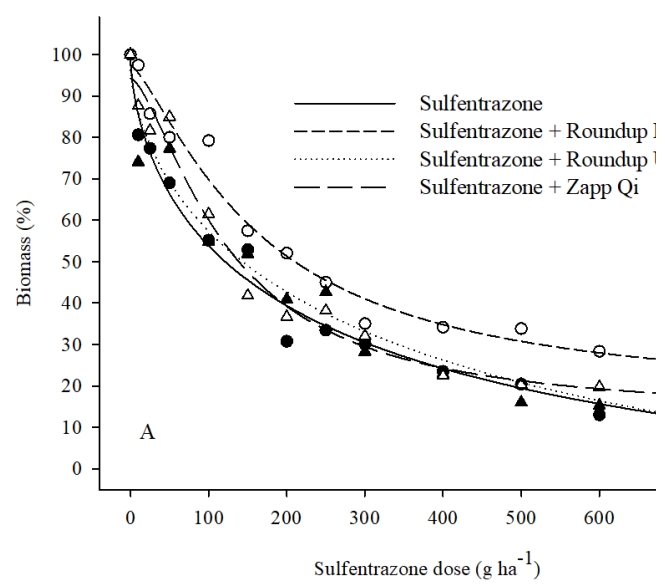

Washed Sand

Sulfentrazone

Sulfentrazone+Roundup Ready ${ }^{\circledR}$

Sulfentrazone+Roundup Ultra ${ }^{\circledR}$

Sulfentrazone+Zapp Qi ${ }^{\circledR}$
Washed Sand

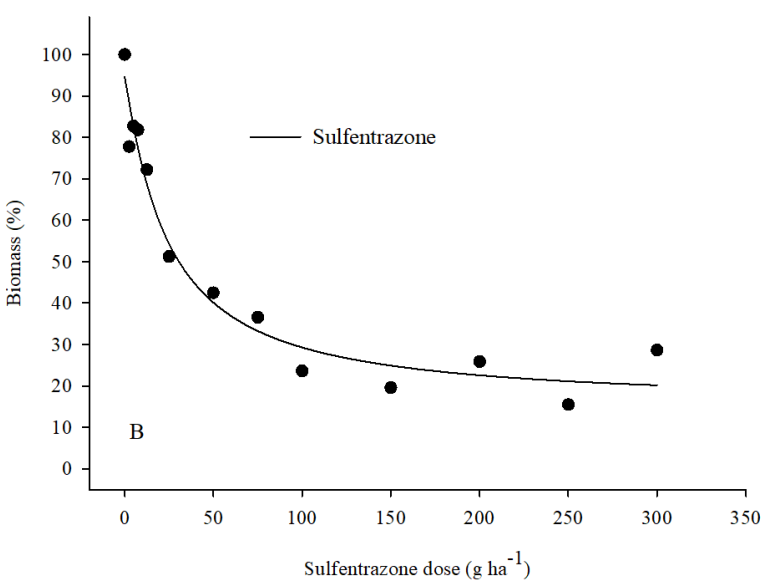

$y=15,3954+\frac{94,5644-15,3954}{1+\left(\frac{x}{24,2820}\right)} \mathrm{R}^{1,0940}=0,9621$

$y=-32,0534+\frac{9498,4525+32,0534}{1+\left(\frac{x}{264,7968}\right)^{0,6737}} \mathrm{R}^{2}=0,9803$

$y=15,6501+\frac{97,4313-15,6501}{1+\left(\frac{x}{165,2689}\right)^{1,3422}} \mathrm{R}^{2}=0,9778$

$y=-45,0776+\frac{96,2557+45,0776}{1+\left(\frac{x}{410,0588}\right)^{0,6864}} \mathrm{R}^{2}=0,9592$

$y=12,3398+\frac{94,2857-12,3398}{1+\left(\frac{x}{124.5853}\right)^{1,5153}} R^{2}=0,9793$

Figure 2. Dry matter of sorghum plants cultivated in Red-Yellow Latosol (A) and washed sand (B) submitted to increasing rates of sulfentrazone alone and mixed with glyphosate at 21 days after sowing.

The rate of glyphosate used was $1080 \mathrm{~g}_{\text {ae ha}}{ }^{-1}$ for all treatments, except sand.

Table 4. Sorption ratio of sulfentrazone isolated and mixed with glyphosate formulations based on plant intoxication at 7,14 and 21 days after sowing (DAS) and dry matter at 21 DAS (DM).

\begin{tabular}{|c|c|c|c|c|}
\hline \multirow{2}{*}{ Treatment } & \multicolumn{4}{|c|}{ Sorption Ratio } \\
\hline & 7DAS & 14DAS & 21DAS & DM \\
\hline Sulfentrazone & 4,00 & 3,47 & 2,91 & 9,90 \\
\hline Sulfentrazone+Roundup Ready ${ }^{\circledR}$ & 7,07 & 6,61 & 5,03 & 5,81 \\
\hline Sulfentrazone+Roundup Ultra ${ }^{\circledR}$ & 4,13 & 6,82 & 6,82 & 15,89 \\
\hline Sulfentrazone+Zapp Qi ${ }^{\circledR}$ & 4,27 & 3,64 & 3,64 & 4,13 \\
\hline
\end{tabular}

The analysis of $\mathrm{P}$ values showed that, at 7 DAS, only the value of $\mathrm{C}_{50}$ regarding the mixture of sulfentrazone with Roundup Ready ${ }^{\circledR}$ differed from sulfentrazone applied alone. However, at 14 and 21 DAS, the $\mathrm{C}_{50}$ values for both sulfentrazone in combination with Roundup Ready ${ }^{\circledR}$ and Roundup Ultra $^{\circledR}$ differed from the $\mathrm{C}_{50}$ found for sulfentrazone applied alone. For the dry matter variable, all formulations differed from the application of sulfentrazone in an isolated form.

The difference in the behaviour of sulfentrazone as a function of the glyphosate formulations may be related to the presence of salts. Glyphosate salts, such as isopropylamine salt
(Roundup Ready ${ }^{\circledR}$ ), ammonium salt (Roundup Ultra $^{\circledR}$ ) and potassium salt (Zapp Qi ${ }^{\circledR}$ ), have different chemical characteristics and may interact differently with sulfentrazone. In these commercial formulations, the surfactants and adjuvants constituting the specific formulation of each trademark may be varied by providing the formulated product with specific characteristics. 
Table 5. Comparison between $\mathrm{C}_{50}$ values considering sulfentrazone mixed with glyphosate formulations in relation to sulfentrazone alone, obtained as function of intoxication at 7, 14 and 21 days after sowing (DAS) and dry matter of plants collected at 21 days after sowing.

\begin{tabular}{lllll}
\hline Ratio & P valor & & & \\
\cline { 2 - 5 } & 7 DAS & 14 DAS & 21 DAS & DM \\
\hline $\begin{array}{l}\text { Sulfentrazone/ } \\
\text { Sulfentrazone+RoundupReady }\end{array}$ & 0,0000 & 0,0000 & 0,000 & 0,000 \\
$\begin{array}{l}\text { Sulfentrazone/ } \\
\text { Sulfentrazone+RoundupUltra }\end{array}$ & 0,7110 & 0,0000 & 0,000 & 0,000 \\
$\begin{array}{l}\text { Sulfentrazone/ } \\
\text { Sulfentrazone+ZappQi }\end{array}$ & 0,4051 & 0,6463 & 0,5422 & 0,000 \\
\hline
\end{tabular}

In the literature, it is reported that $96 \%$ of farmers perform applications of agrochemicals in tank mixtures, and $86 \%$ reported that two or more herbicides were present in this mixture (GAZZIERO, 2015). The association of herbicides aims to increase the control spectrum as well as to control specific species or biotypes. In addition, the application of herbicides with different mechanisms of action is a fundamental tool for the management of resistant and tolerant populations. However, caution should be used, because little is known about the behaviour of the molecules when applied in admixture.

\section{CONCLUSION}

Application of sulfentrazone mixed with glyphosate alters the sulfentrazone sorption forces in Red-Yellow Latosol. Based only on the intoxication of the indicator plants, glyphosate formulations, in general, increase sulfentrazone sorption in RedYellow Latosol, reducing availability in soil solution. However, taking into account the accumulation of dry matter of plants grown on substrates treated with sulfentrazone alone and mixed with glyphosate formulations, sulfentrazone sorption was found to increase as a result of mixing with Roundup Ultra ${ }^{\circledR}$, but decreased when in combination with Roundup Ready ${ }^{\circledR}$ and Zapp Qi ${ }^{\circledR}$.

RESUMO: A utilização de herbicidas pertencentes a um único mecanismo de ação por vários anos consecutivos na mesma área pode levar a seleção de biótipos de plantas daninhas resistentes a herbicidas. Plantas daninhas resistentes ao glyphosate têm sido problema no mundo inteiro. Como alternativa de controle, os agricultores têm utilizado glyphosate em mistura com sulfentrazone. Quando se misturam duas moléculas herbicidas, os parâmetros que governam o comportamento de herbicidas no solo podem ser alterados. Neste estudo foi estimada a sorção do sulfentrazone quando aplicado de forma isolada e em mistura com formulações de glyphosate. Para isso, doses crescentes de sulfentrazone foram aplicadas utilizando-se como substrato Latossolo Vermelho-Amarelo e areia lavada. Cada uma das doses de sulfentrazone foi aplicada em mistura com $1080 \mathrm{~g} \mathrm{ha}^{-1}$ de glyphosate comercializado nas formulações Roundup Ready ${ }^{\circledR}$, Roundup Ultra ${ }^{\circledR}$ e Zapp Qi ${ }^{\circledR}$. Para avaliar a presença do sulfentrazone na solução do solo utilizou-se o Sorghum bicolor como espécie indicadora. Os sintomas de intoxicação foram avaliados aos 7, 14 e 21 dias após a semeadura. Aos 21 dias após a semeadura, as plantas foram coletadas e secadas em estufa a $70 \pm 1^{\circ} \mathrm{C}$ para determinação da matéria seca. Com base na intoxicação das plantas indicadoras, verificou-se que, independente da formulação, a presença glyphosate na mistura, aumentou a sorção do sulfentrazone no Latossolo Vermelho-Amarelo. No entanto com base no acúmulo de matéria seca, constatou-se que a sorção do sulfentrazone aumentou em função da mistura com Roundup Ultra ${ }^{\circledR}$, mas diminuiu devido a presença de Roundup Ready ${ }^{\circledR}$ e Zapp Qi ${ }^{\circledR}$. Conclui-se que a aplicação de sulfentrazone em mistura com glyphosate altera as forças sortivas do sulfentrazone no Latossolo Vermelho-Amarelo.

PALAVRAS-CHAVE: Herbicida. Comportamento. Solo. Bioensaio. Sorghum bicolor. 


\section{REFERENCES}

BAIO, F. H. R.; GABRIEL, R.R.F.; CAMOLESE, H.S. Alteração das propriedades físico-químicas na aplicação contendo adjuvantes. Revista Brasileira de Engenharia de Biossistemas, Tupã - SP, v. 9, n. 2, p. 151-161, 2015. https://doi.org/10.18011/bioeng2015v9n2p151-161

BORGGAARD, O.K.; GIMSING, A.L. Fate of glyphosate in soil and the possibility of leaching to ground and surface waters: a review. Pest and Management Science, West Sussex, v. 64, p. 441-456, 2008.

https://doi.org/10.1002/ps.1512

ČADKOVÁ, E.; KOMÁREK, M.; KALISZOVÁ, R.; VANĚK, A.; MILUŠE BALÍKOVÁ. Tebuconazole sorption in contrasting soil types. Soil and Sediment Contamination: An International Journal, Amherst MA, v. 22, n. 4, p. 404-414, 2013. https://doi.org/10.1080/15320383.2013.733448

COUTINHO, C. F. B.; MAZO, L. H. Complexos metálicos com o herbicida glifosato: revisão. Química Nova, São Paulo - SP, v. 28, n. 6, p. 1038-1045, 2005. https://doi.org/10.1590/S0100-40422005000600019

DA CUNHA, J. P. A. R.; ALVES, G. S. Características físico-químicas de soluções aquosas com adjuvantes de uso agrícola. Interciência, Caracas, v. 34, n. 9, p. 655-659, 2009.

FMC Corporation. 1999. Sulfentrazone. Product Profile. Philadelphia: Agricultural Product Group.

FRANS, R.; TALBERT, R.; MARX, D.; CROWLEY, H. Experimental design and techniques for measuring and analyzing plant responses to weed control practices. In: CAMPER, N.D. (Ed.) Research methods in weed science. 3 ed. Champaign: Southern Weed Science Society, 1986. 37p.

GAZZIERO, D. L. P. Misturas de agrotóxicos em tanque nas propriedades agrícolas do Brasil. Planta Daninha, Viçosa, v. 33, n. 1, p. 83-92, 2015. https://doi.org/10.1590/S0100-83582015000100010

GHERARDI-GOLDSTEIN, E.; BERTOLETTI, E.; ZAGATTO, P. A.; ARAÚJO, R. P. A.; RAMOS, M. L. L. C. Procedimentos para Utilização de Testes de Toxicidade no Controle de Efluentes Líquidos. CETESB, São Paulo, 1990.

GREY, T. L.; WALKER, R. H.; WEHTJE, G. R.; HANCOCK, H. G. Sulfentrazone adsorption and mobility as affected by soil and pH. Weed Science, Washington, v. 45, n. 5, p. 733-738, 1997.

HATZIOS, K. K. 1998. Supplement to Herbicide Handbook. 7th ed. Lawrence, K S: Weed Science Society of America. Pp. 67-69.

MAIN, C. L.; MUELLER, T. C.; HAYES, R. M.; WILCUT, J. W.; PEEPER, T. F.; TALBERT, R. E.; WITT, W. W. Sulfentrazone persistence in southern soils: bioavailable concentration and effect on a rotational cotton crop. Weed Technology, Washington, v. 18, n. 2, p. 346-352, 2004. https://doi.org/10.1614/WT-03091R1

MARCHESE, L. Sorção/dessorção e lixiviação do herbicida ametrina em solos canavieiros tratados com lodo de esgoto. 2007. Dissertação (Mestrado em Ciências) Universidade de São Paulo, Piracicaba, 2007.

MARTINEZ, C. O.; SILVA, C.M.M.S.; FAY, E. F.; MAIA, A.H.N.; ABAKERLI, R. B.; DURRANT, L. R. Degradation of the herbicide sulfentrazone in a Brazilian Typic Hapludox soil. Soil Biology and Biochemistry, Leicestershire, v. 40, p. 879-886, 2008. https://doi.org/10.1016/j.soilbio.2007.10.016

MASHAYAMOMBE, B.K.; MAZARURA, U.; CHITEKA, A. The effect of two formulations of sulfentrazone on soil and leaf residues and phytotoxicity in tobacco (Nicotiana tabacum L.). Asian Journal of Agriculture and Rural Development, Bahawalpur, v. 3, n. 3, p.135-140, 2013. 
MINOZZI, G.B.; MONQUERO, P.A.; PEREIRA, P.A. Eficácia de diferentes manejos das plantas daninhas na cultura da soja transgênica. Revista Brasileira de Ciências Agrárias, v. 9, n. 3, p. 406-412, 2014. https://doi.org/10.5039/agraria.v9i3a4499

NALINI, R.R.P; JANAKI, P.; BALUSAMY, M.; CHINNUSAMY, C. Persistence of sulfentrazone in soil under soybean and its carryover effect on bioindicators. Acta Agriculturae Scandinavica, Section B - Soil \& Plant Science, Uppsala, v.67, n.3, p. 217-222, 2016. https://doi.org/10.1080/09064710.2016.1246670

OHMES, G. A.; HAYES, R. M.; MUELLER, T. C. Sulfentrazone dissipation in a Tennessee soil. Weed Technology, Washington, v. 14, n. 1, p. 100 -105, 2000. https://doi.org/10.1614/0890037X(2000)014[0100:SDIATS]2.0.CO;2

OHMES, G. A.; MUELLER, T. C. Sulfentrazone adsorption and mobility in surface soil of the southern United States. Weed Technology, Washington, v. 21, n. 3, p. 796-800, 2007. https://doi.org/10.1614/WT-06-185.1

PESSALA, P.; SHULTZ, E.; NAKARI, T.; JOUTTI, A.; HERVE, S. Evaluation of wastewater effluents by small-scallebiotests and a fractionation procedure. Ecotoxicology and Environmental Safety, Plymouth, v. 59, n. 2, p. 263-272, 2004. https://doi.org/10.1016/j.ecoenv.2003.10.002

PRATA, F.; LAVORENTI, A.; REGITANO, J. B.; TORNISIELO, V. L. Influência da matéria orgânica na sorção e dessorção do glifosato em solos com diferentes atributos mineralógicos. Revista Brasileira de Ciência do Solo, Viçosa, n. 24, p. 947-951, 2000. https://doi.org/10.1590/S0100-06832000000400026

PRATA, F. LAVORENTI, A.; REGITANO, J. B.; VEREECKEN, H.; TORNISIELO, V. L.; PELISSARI, L. Glyphosate behavior in a Rhodic Oxisol under no-till and conventional agricultural systems. Revista Brasileira de Ciência do Solo, Viçosa, v. 29, n. 1, p. 61-69, 2005. https://doi.org/10.1590/S0100-06832005000100007

RAYA-RODRIGUEZ, M. T. O uso de bioindicadores para avaliação da qualidade do ar em Porto Alegre. IN: ZURITA M. L. L. \& TOLFO, A. M. (Org.). A Qualidade do Ar em Porto Alegre. Secretaria Municipal do Meio Ambiente, Porto Alegre, 2000.

SANDÍN -ESPAÑA, P., LOUREIRO, I., ESCORIAL, C., CHUECA, C., SANTIŃ -MONTANYA, I. 2011. The Bioassay Technique in the Study of the Herbicide Effects, Herbicides, Theory and Applications, Prof. Marcelo Larramendy (Ed.), ISBN: 978-953-307-975-2, InTech. Disponívem em: Available from: https://www.intechopen.com/books/herbicides-theory-and-applications/the-bioassay-technique-in-the-study-ofthe-herbicide-effects. https://doi.org/10.5772/13571

SEEFELDT, S.S.; JENSEN, S.E.; FUERST, E.P. Log-logistic analysis of herbicide dose-response relationship. Weed Technology, Washington, v.9, n. 2, p.218-227, 1995. https://doi.org/10.1017/S0890037X00023253

SHANER, D.L. Field dissipation of sulfentrazone and pendimethalin in Colorado. Weed Technology, Washington, v. 26, n.4, p. 633-637, 2012. https://doi.org/10.1614/WT-D-12-00037.1

SILVA, A. A., VIVIAN, R., OLIVEIRA Jr., R. S. Herbicidas: comportamento no solo. In: SILVA, A. A.; SILVA, J. F. (Ed.) Tópicos em manejo de plantas daninhas. Viçosa, MG: Universidade Federal de Viçosa, p. 189-248, 2013.

SOUZA, M. F.; NETO, M.D.C.; MARINHO, M.I.; SARAIVA, D.T.; FARIA, A.T; SILVA, A.A.; SILVA, D.V. Persistence of imidazolinones in soils under a clearfield system of rice cultivation. Planta Daninha, Viçosa, v. 34, n. 3, p. 589-596, 2016. https://doi.org/10.1590/s0100-83582016340300020

SOUZA, M. F. Dinâmica do atrazine no solo em aplicações isoladas e em misturas com formulações de glyphosate. 2017. 55 p. Dissertação de Mestrado - Departamento de Fitotecnia, Universidade Federal de Viçosa. 
STREIBIG, J.C.; RUDEMO, M.; JENSEN, J.E. Dose-response curves and statistical models. In: STREIBIG, J.C; KUDSK, P. (Ed.) Herbicide bioassay. Boca Raton: CRC Press, 1993. p.30-35.

SZMIGIELSKI, A.M.; SCHOENAU, J.J.; JOHNSON, E.N.; HOLM, F.A.; SAPSFORD, K.L.; LIU, J.

Development of a laboratory bioassay and effect of soil properties on sulfentrazone phytotoxicity in soil. Weed Technology, Washington, v. 23, n. 3, p. 486-491, 2009. https://doi.org/10.1614/WT-08-122.1

TONI, L.R.M.; SANTANA, H.; ZAIA, D.A.M. Adsorção de glifosato sobre solos e minerais. Química Nova, São Paulo, v. 29, n. 4, p. 829-833, 2006. https://doi.org/10.1590/S0100-40422006000400034 